\title{
Home fall of elderly people: implications of stressors and representations in the COVID-19 context
}

\author{
Queda domiciliar de idosos: implicações de estressores e \\ representações no contexto da COVID-19 \\ Caída de ancianos en casa: implicaciones de estresores y \\ representaciones en el contexto de COVID-19
}

\section{Jéssica de Castro Santos ${ }^{a}$ Cristina Arreguy-Sennab Paulo Ferreira Pinto ${ }^{c}$ Elenir Pereira de Paiva ${ }^{b}$ Pedro Miguel dos Santos Dinis Parreira ${ }^{d}$ Marcos Antônio Gomes Brandãoa}

\section{How to cite this article:} Santos $J C$, Arreguy-Senna C, Pinto PF, Paiva EP, Parreira PMSD, Brandão MAG Home fall of elderly people: implications of stressors and representations in the COVID-19 context. Rev Gaúcha Enferm. 2021;42(spe):e20200221. doi: https://doi.org/10.1590/19831447.2021.20200221 a Universidade Federal do Rio de Janeiro (UFRJ), Escola de Enfermagem Anna Nery. Rio de Janeiro, Rio de Janeiro, Brasil.

- Universidade Federal de Juiz de Fora (UFF), Faculdade de Enfermagem. Juiz de Fora, Minas Gerais, Brasil.

Universidade Federal de Juiz de Fora (UFF), Faculdade de Educação Física e Desportes. Juiz de Fora, Minas Gerais, Brasil.

Universidade de Coimbra (UC), Escola Superior de Enfermagem de Coimbra. Coimbra, Portugal.

\section{ABSTRACT}

Objectives: To describe personal conditions and home structure that predisposes the elderly to the risk of falling, in the perspective of Neuman's stressors; to describe the content, structure and origin of social representations about falling at home by elderly people; and conjecture the implications of this empirical evidence on the daily lives of the elderly in the context of the pandemic caused by COVID-19.

Method: Mixed method with concomitant triangulation (January-July/2017), qualitative design (structural and procedural approaches to the Social Representations Theory) and quantitative (sectional) approaching elderly people $\geq 65$ years.

Results: Environmental factors were identified for falling at home, fear of activities of daily living and loss of visual acuity. Feelings and behaviors mentioned in the possible central nucleus justified the modulation of behaviors. Analysis categories: 1) Representation of the (in)adaptability of the home environment; 2) Representation and overcoming limitations arising from weaknesses.

Conclusion: It was possible to produce conjectures based on empirical evidence in the current situation in the pandemic's dynamics. Keywords: Accidental falls. Aged. Housing. Coronavirus infections. Geriatric nursing. Nursing theory.

\section{RESUMO}

Objetivos: Descrever condições pessoais e estrutura domiciliar que predispõe a pessoa idosa ao risco de queda, na perspectiva de estressores de Neuman; descrever os conteúdos, a estrutura e a origem das representações sociais sobre queda no domicílio por pessoas idosas; e conjecturar as implicações destas evidências empíricas sobre o cotidiano de idosos no contexto da pandemia ocasionada pelo COVID-19.

Método: Método misto com triangulação convergente (janeiro-julho/2017), delineamento qualitativo (abordagens estrutural e processual da Teoria das Representações Sociais) e quantitativo (seccional) abordando idosos ( $\geq 65$ anos).

Resultados: Identificaram-se fatores ambientais para queda no domićlio, medo diante das atividades de vida diária e perda da acuidade visual. Sentimentos e comportamentos mencionados no possível núcleo central justificaram a modulação de comportamentos. (ategorias de análise: 1) Representação da (in)adaptabilidade do ambiente domiciliar; 2) Representação e superação de limitações advindas das fragilidades.

Conclusão: Foi possível produzir conjecturas sustentadas nas evidências empíricas na situação atual na dinâmica da pandemia. Palavras-chave: Acidentes por quedas. Idoso. Habitação. Infecções por coronavírus. Enfermagem geriátrica. Teoria de enfermagem.

\section{RESUMEN}

Objetivos: Describir las condiciones personales y la estructura del hogar que predispone a los ancianos al riesgo de caerse, en la perspectiva de los factores estresantes de Neuman; Describir el contenido, la estructura y el origen de las representaciones sociales sobre el hecho de caer en el hogar por personas mayores. y conjetura las implicaciones de esta evidencia empírica en la vida cotidiana de los ancianos en el contexto de la pandemia causada por COVID-19.

Método: método mixto con triangulación concomitante (enero-julio / 2017), diseño cualitativo (enfoques estructurales y procesales de la teoría de las representaciones sociales) y enfoque cuantitativo (seccional) para personas mayores $\geq 65$ años.

Resultados: Se identificaron factores ambientales para caerse en casa, miedo a las actividades de la vida diaria y pérdida de agudeza visual. Los sentimientos y los comportamientos mencionados en el posible núcleo central justificaron la modulación de los comportamientos. (ategorías de análisis: 1) Representación de la (in) adaptabilidad del entorno del hogar; 2) Representación y superación de limitaciones derivadas de debilidades.

Conclusión: Fue posible producir conjeturas basadas en evidencia empírica en la situación actual de la dinámica de la pandemia. Palabras clave: Accidentes por caídas. Anciano. Vivienda. Infecciones por coronavirus. Enfermería geriátrica. Teoría de enfermería. 


\section{口INTRODUCTION}

The human aging process is accompanied by biophysiological and psychosociocultural changes that influence the increase in chronic diseases, polypharmacy, vulnerability to falls and self-perception of itself, interpersonal relationships, the environment and the values attributed to everyday circumstances ${ }^{(1)}$. Therefore, this period of life requires that the environments where people find themselves to be readjusted. The desired goal aims to add personal safety and to contribute to the prevention of falls. Among external causes, falls represent a growing public health problem, it is the second leading cause of accidental deaths worldwide ${ }^{(2)}$.

Each year, approximately 646,000 individuals die due to falls worldwide, from which more than $80 \%$ occur in low and middle income countries. Elderly aged $\geq 65$ years old suffer some accident due to fall each year, this proportion being intensified in the age group of elderly aged $\geq 70$ years old. Elderly people suffer the greatest number of fatal falls, each year an average of 37.3 million severe falls occur enough to require medical attention ${ }^{(2)}$.

The falls impact on health costs, family dynamics and the socialization process ${ }^{(3)}$. Many of these falls occur at home. Therefore, the environmental household structure must be adapted to the demands of the aging process, since this is considered the place where most activities of daily living are carried out, and where elderly people tend to spend most of their time. Degenerative conditions tend to restrict the elderly to this environment, or even circumstantial conditions to restrict circulation in external environments, similar to the recommendations arising from the dissemination of Covid-19(4). Thus, it constitutes the challenge of reconciling social restriction with the active aging paradigm that is based on maximum autonomy, social participation, security and adding quality to the lived years and the gap identified in the literature when thinking about the safety of the elderly person in the context of the pandemic caused by the new coronavirus.

The home, from the perspective of assessing vulnerability to falling, is being conceived as the physical, emotional, cultural and architectural structure of the residences and/or rooms that includes the objects and culturally defined aesthetic options, for the internal environment of the residences, in addition to the premises and external areas contained within the boundaries of real estate where the elderly person resides or is momentarily or temporarily.

There is a recommendation for these environments to be accessible, safe, and free of risk factors for fall ${ }^{(5)}$. The elderly person's self-perception about the home environment allows them to access their cultural, psychosocial and architectural understanding of these places from their individual and collective perspective.
In the broader field of social sciences, addressing the fall in the procedural(6) and structural(7) perspective of the Social Representations Theory (SRT) is justified by: 1) consensus- portraying the vulnerability of the elderly social group, explaining behaviors, sensations and attitudes; 2) relevance - constituting a social object that can be accessed by communicational processes by social actors; 3 ) practicerefer to a problem in your daily life that impacts on health and well-being; 4) holomorphosis- allowing access to habits, mores and behaviors of preventable social actors in everyday household and 5) affiliation- portraying the context of its incidence ${ }^{(8)}$.

This is equivalent to affirming that the fall (object of representation) is anchored (ability to approach the object of investigation to the daily life of the investigated person) and objectified (ability of the person to give concreteness to the contents shared socially) by the elderly people (social subjects).

In the field of nursing discipline, the elements of a nursing theory can provide relevant categories to guide professional assessment and intervention. Neuman's systems theory ${ }^{(9)}$ points to the concept of stressors that are useful elements to capture the perspective of the elderly person with intrapersonal, interpersonal and extrapersonal origin. So, stressors can help the health team, especially nurses, in the professional approach to the fall of the elderly and in the structuring of interventions at the primary, secondary, and tertiary levels. The consequence of proper handling of stressors is to help maintain the balance of the person's energy systems ${ }^{(9)}$.

In the context of the restriction of social isolation derived from the pandemic by COVID-19 the present study gains more relevance. It is estimated that the restriction to the home can increase the influence of stressors and increase the incidence of falls among elderly people. It is reiterated that because the mortality related to the virus infection is higher in the elderly, significant attention is directed to the disease process and its biological consequences, which may represent an underestimation of the home risk factors for falling.

In view of the above, the following research question was elaborated: How would the stressors identified in the elderly person associated with the vulnerability to fall at home conform in the context of the COVID-19 pandemic?

The objectives are: Describe personal and home structure conditions that predispose the elderly person to the risk of falling, from the perspective of Neuman's stressors; describe the content, structure and origin of social representations about falling at home by elderly people and conjecture the implications of this empirical evidence on the daily lives of the elderly in the context of the pandemic caused by COVID-19. 


\section{METHOD}

Mixed method study with concomitant triangulation ${ }^{(10)}$ and data mixing integrating qualitative approaches (Social Representations Theory in structural ${ }^{(7)}$ and procedural approaches ${ }^{(6)}$ and BettyNeuman's Nursing Theory $\left.{ }^{(9)}\right)$ and quantitative ${ }^{(11)}$ (sectional study), presented according to criteria proposed by the Mixed Methods Appraisal Tool (MMAT), version $2018^{(12)}$ and production of conjectural extrapolations in the form of implications about the daily life of the elderly in the context of the pandemic by COVID-19.

The scenario of the pre-pandemic empirical investigation was the home of elderly people in an area attached to a Primary Health Care Unit (PHCU) in Minas Gerais, whose choice of unit was based on the fact that the majority of authors have ties with elderly people due to the development of teaching, research and extension activities, a favorable condition for conducting an in-depth interview. It is a mixed model PHCU in which the Family Health Strategy (FHS) coexists with the Community Health Agents Program (CHAP) covering more than 50 thousand inhabitants and, because the neighborhood has a higher than national average percentage of elderly people. Participated in the study elderly people aged $\geq 65$ years, whose criterion was due to the fact that this investigation integrates a matrix research that intended to compare its results with international data where the elderly is conceived as being aged equal to or above this cutoff point. The sample calculation was performed with the support of the GPower 3.1 software, considering the criteria of mean effect size, $a$ of 0.05 and $\beta$ of 0.80 . Thus, the sample indicated was 200 subjects for the chi-square test ${ }^{(13)}$. There was replacement in case of loss $\geq 10 \%$ in any of the stages.

Eligibility criteria were: being $\geq 65$ years old, walking, lucid and with coherent speech. Hospitalized elderly people who traveled or moved during the data collection period or were not found after three consecutive visits were excluded. There were 10 losses motivated by: deaths (three), refusals (four); change residence (one), change in cognitive deficit during the data collection period (one) and hospitalization (one). Recruitment was carried out at home by individual invitation, on the occasion of extension and research activities.

The data collection instrument was consisted by: a sectional study (sociodemographic characterization, intervening factors for falls: view according to the Snellen scale ${ }^{(14)}$ and Jaeger ${ }^{(14)}$, FES scale ${ }^{(15)}$ and self-perception of the environment), structural approach of the SRT using the technique of free association of words triggered by icons (TFAWTI) ${ }^{(2)}$ from the inductive term "fall at home"; and SRT's procedural approach (field diary, interviews triggered by the guiding question: Tell me about a case of falling at home that occurred with you, with someone you know or heard about).
The data collection process took place in January-July/2017, in simultaneous stages, respecting the methodological rigor and equivalence of each approach. Three visits were made to each participant, alternating the qualitative and quantitative approaches to obtain the data. It was carried out by two properly trained researchers and, in order to reduce time and minimize typing bias, it was used the Open Data Kit application on an Android ${ }^{\circledR}$ device. An in-depth interview was conducted with audio recording whose average time was 20 minutes (variability from 15 to 30 minutes) influenced by the participant's profile and included the discursive contents and cursive records in the field diary about the social context and evidence of non-verbal communication.

Quantitative data were treated in the SPSS ${ }^{\circledR}$ program using descriptive statistics (measures of dispersion and centrality). The cognemas that emerged from the technique of free evocation of words were treated by the dictionary technique of equivalent terms (lexicographic and semantic analysis) aiming to homogenize them, followed by the prototypical analysis and use of the Zipf Law, being elaborated the four quadrant chart via EVOC $2000^{\circledR}$ Software. 931 cognemas were evoked, 196 distinct with use of $48 \%$ of the corpus. A minimum frequency of 22 was chosen; intermediate frequency of 80 and average evocation order of 2.7.

The contents of speeches from the procedural approach were treated by content analysis, following the following stages 1) pre-analysis; 2) material exploration; 3) treatment of the results obtained and interpretation ${ }^{(16)} u$ using input from NVIVO pro $11^{\circledR}$, whose thematic categories were established a priori (representational dimensions and origin of symbolic constructions) adopting thematic-categorical content analysis that made it possible to configure the units of analysis and registration through categories that were composed using the corpus contained in the "nodes" in order to ensure theoretical density through sequential regrouping according to thematic category. Theoretical density proved by Pearson's correlation $\geq 0.70^{(17)}$.

The results were approximated to provide convergent analysis by triangulating the results of the structural and procedural approaches of the SRT with the quantitative data that were analyzed and discussed in the light of the concept of stressors proposed by Neuman, aiming to identify the contents that were in agreement and disagreement for the different approaches.

The study was approved by the locus institution with Certificate of Presentation of Ethical Appreciation No. $48116115,0,0000,5147$ and statement No.1,297,770. Participants were informed about the objectives of the study and signed $a$ free and informed consent form. To guarantee 
the participants' anonymity, the studies were identified by alphanumeric codes (letter $\mathrm{P}$, followed by three sequential numeric digits).
To exemplify the description of the methodological aspects of the study, Chart 1 is presented that summarizes the content.

\section{Mixed Method with Concomitant Triangulation}

\begin{tabular}{|c|c|c|}
\hline \multirow{2}{*}{ Study design } & Qualitative & Quantitative \\
\hline & Structural and procedural approach of SRT & Sectional study \\
\hline \multirow[t]{2}{*}{ Objectives } & $\begin{array}{l}\text { Describe the content, structure and origin of } \\
\text { social representations about falling at home by } \\
\text { elderly people }\end{array}$ & $\begin{array}{l}\text { Describe personal and home structure } \\
\text { conditions that predispose the elderly } \\
\text { to the risk of falling, in the perspective of } \\
\text { Neuman's stressors }\end{array}$ \\
\hline & \multicolumn{2}{|c|}{$\begin{array}{l}\text { Conjecture the implications of this empirical evidence on the daily life of the elderly in the context o } \\
\text { the pandemic caused by COVID-19. }\end{array}$} \\
\hline \multirow{2}{*}{$\begin{array}{l}\text { Participants } \\
\text { Data collect }\end{array}$} & $\begin{array}{l}190 \text { participants - sample group of the } \\
\text { structural approach } \\
50 \text { participants - sample group of the } \\
\text { procedural approach }\end{array}$ & 190 elderly people \\
\hline & $\begin{array}{l}\text { TFAWTI } \\
\text { Semi-structured interview with audio recording }\end{array}$ & $\begin{array}{l}\text { Sociodemographic characterization } \\
\text { Application of the Snellen and Jaeger scales for } \\
\text { visual acuity } \\
\text { Application of the FES-I scale } \\
\text { Self-perceived risk of falls }\end{array}$ \\
\hline Data analysis & $\begin{array}{l}\text { Semantic and lexicographic analysis followed by } \\
\text { prototypical analysis } \\
\text { Content analysis } \\
\text { EVOC } 2000^{\circledR} \text {. } \\
\text { NVIVO pro } 11^{\circledR}\end{array}$ & $\begin{array}{l}\text { Descriptive and correlational statistics } \\
\text { (univariate analysis) } \\
\text { SPSS }^{\circledR} \text {, version } 22\end{array}$ \\
\hline
\end{tabular}

Chart 1 - Descriptive synthesis of the methodology Source: Authors, 2020.

\section{RESULTS}

The participants presented the sociodemographic characterization shown in Table 1.

To characterize the situations and circumstances of vulnerability to falls related to interpersonal stressors, it was identified: 1) visual acuity according to Snellen (in $54.1 \%$ of visual difficulty in the left eye and $50.6 \%$ in the right, which corresponds to reading ability less than or equal to $5(20 / 40)$; 2) visual acuity according to Jaeger (respectively, $55.2 \%$ and $53.2 \%$ did not see anything or saw poorly with the left and right eyes and $41.6 \%$ could see poorly with the left and right eyes); 3) With the Falls Efficacy Scale (FES), variability from 16 to 55 points and standard deviation of 12.36 were identified, whose centrality measures were: average of 24.51 points; median 22 points and fashion 18 points. 53.5\% participants are considered to be fallers, due to the fact that they obtain a score greater than 23 points on the FES Scale, indicating that most participants have a feeling of fear in the development of their activities of daily living.

Transpersonal stressors are shown in Table 2. They were identified from the self-perception of vulnerability, in which 
Table 1 - Characterization of the 190 participants according to gender, age, skin color, schooling, marital status and number of children. Juiz de Fora, May/2020.

\begin{tabular}{|c|c|c|c|c|c|c|c|}
\hline Variables & $\mathbf{N}$ & $\%$ & & Variables & $\mathbf{N}$ & $\%$ & $\begin{array}{c}\mu \pm S D \\
(\max -\min )\end{array}$ \\
\hline Gender & & & & Age & & & \\
\hline Male & 41 & 21.5 & & 65---69 & 50 & 26.3 & $\begin{array}{c}\mu 75.01 \pm 7.109 \\
(65-96)\end{array}$ \\
\hline Female & 149 & 78.5 & & 70---74 & 54 & 28.5 & \\
\hline \multirow[t]{2}{*}{ Total } & 190 & 100 & & 75---79 & 30 & 15.7 & \\
\hline & & & & 80---84 & 33 & 17.3 & \\
\hline Skin Color & & & & $\geq 85$ & 23 & 12.2 & \\
\hline White & 132 & 69.4 & & Total & 190 & 100 & \\
\hline Black & 11 & 5.6 & & & & & \\
\hline Brown & 46 & 24.5 & & Marital Status & & & \\
\hline Not mentioned & 1 & 0.5 & & Single & 10 & 5.2 & \\
\hline \multirow[t]{2}{*}{ Total } & 190 & 100 & & Married & 126 & 66.3 & \\
\hline & & & & Separated & 9 & 4.7 & \\
\hline Schooling & & & $\begin{array}{c}\mu 4.85 \pm 4.63 \\
\quad(0-18)\end{array}$ & Widower & 41 & 21.5 & \\
\hline $01-5$ years & 155 & 81.5 & & Stable union & 4 & 2.3 & \\
\hline $5 \mathrm{I}-8$ years & 14 & 7.5 & & Total & 190 & 100 & \\
\hline $8 \mid-12$ years & 7 & 3.7 & & & & & \\
\hline$\geq 12$ years & 14 & 7.3 & & Personal income & & & \\
\hline \multirow[t]{3}{*}{ Total } & 190 & 100 & & 0 & 4 & 2.1 & $\begin{array}{c}\mu 1.91 \pm 2.519 \\
(0-18)\end{array}$ \\
\hline & & & & 11-------3 & 92 & 48.4 & \\
\hline & & & & 3|--------5 & 12 & 6.3 & \\
\hline
\end{tabular}


Table 1 - Cont.

\begin{tabular}{|c|c|c|c|c|c|c|c|}
\hline Variables & $\mathbf{N}$ & $\%$ & & Variables & $\mathbf{N}$ & $\%$ & $\begin{array}{c}\mu \pm S D \\
\text { (max-min) }\end{array}$ \\
\hline Have children & & & & $\geq 5$ & 7 & 3.1 & \\
\hline Yes & 98 & 51.7 & & Did not answer & 76 & 40 & \\
\hline No & 92 & 48.3 & & Total & 190 & 100 & \\
\hline \multirow[t]{2}{*}{ Total } & 190 & 100 & & & & & \\
\hline & & & $\begin{array}{c}\mu 3.56 \pm 1.814 \\
(1-10)\end{array}$ & Family income & & & \\
\hline Number of children & & & 0 & - & - & $\begin{array}{l}\mu 3.20 \pm 2.629 \\
(1-18)\end{array}$ & \\
\hline 0 & 92 & 48.3 & & $11-------3$ & 62 & 32.6 & \\
\hline $11-------3$ & 28 & 14.9 & & 3|--------5 & 31 & 16.4 & \\
\hline 3|--------5 & 41 & 21.5 & & $\geq 5$ & 20 & 10.5 & \\
\hline$\geq 5$ & 29 & 15.3 & & Did not answer & 77 & 40.5 & \\
\hline Total & 190 & 100 & & Total & 190 & 100 & \\
\hline
\end{tabular}

Source: Data from the matrix research, 2017.

there was a $\geq 10 \%$ difference for situations involving a safety bar, slippery floor, uneven floor or with holes, stairs and handrail and self-perceived as less intensity in $2 \%$ to $3 \%$ of difference for situations where there are steps, and many objects present in the environment. The comparative analysis was significant for slippery floors, stairs and handrails ( $p$-value $\leq 0.04$ ).

The data emerging from the qualitative approach refer to interpersonal, intrapersonal, and transpersonal stressors. After prototypical analysis, the evoked contents were allocated as shown in Figure 1.

Chart 2 presents the product of the thematic-categorical content analysis, two categories emerged, namely: 1) Representation of the (in)adaptability of the home environment and 2) Representation and overcoming limitations arising from weaknesses; which follow accompanied by fragments of the participants' discourse exemplifying the categories, according to the representational dimensions (behavioral/ attitudinal, cognitive/informational, evaluative and objective), and the stressors (intrapersonal, interpersonal and extrapersonal according to the representational origins).
It is worth mentioning that the dendrogram and the circle graph of the representational contents and the stressors demonstrate the formation of the emerged categories and the theoretical density.

\section{DISCUSSION}

The predominance of women among the elderly population and the tendency to stay more hours in activities at home may be one of the factors to explain the greater number of women in the sample.

In the context of recommendations for staying at home to prevent contamination by the COVID-19 virus, factors of gender differences stand out due to the different way of engaging with norms, roles and social relations, in adhering to health goals, namely in health promotion, disease prevention and health interventions. Women tend to engage more intensely in healthy lifestyle habits, which tend to expand the elderly female population, although they are more vulnerable to falls when compared to men ${ }^{(18)}$. On 
Table 2 - Vulnerability to fall measured from self-perception according to the Falls Efficacy Scale and theoretical conjectures about everyday life in the context of the pandemic. MG, Brazil, 2017

\begin{tabular}{|c|c|c|c|c|c|c|}
\hline \multirow{4}{*}{$\begin{array}{l}\text { Variable of } \\
\text { interest }\end{array}$} & \multicolumn{5}{|c|}{ Empirical research } & \multirow{4}{*}{$\begin{array}{l}\text { Theoretical conjecture } \\
\text { Hypothesis of change } \\
\text { in the context of the } \\
\text { COVID-19 pandemic }\end{array}$} \\
\hline & \multicolumn{5}{|c|}{ Activity measured for situation at home } & \\
\hline & \multicolumn{2}{|c|}{ Non-falling people } & \multicolumn{2}{|c|}{ Falling people } & \multirow{2}{*}{$\mathbf{X}^{2}$} & \\
\hline & $\mathbf{N}$ & $\%$ & $\mathbf{N}$ & $\%$ & & \\
\hline Rug & 46 & 48.4 & 49 & 51.6 & 0.365 & YES \\
\hline Security bar & 12 & 36.4 & 21 & 63.6 & 0.530 & YES \\
\hline Good lighting & 68 & 49.6 & 69 & 50.4 & 0.241 & NO \\
\hline Slippery floor & 20 & 31.3 & 44 & 68.8 & 0.000 & YES \\
\hline Steps & 72 & 51.1 & 69 & 48.9 & 0.848 & NO \\
\hline Stairs & 29 & 39.2 & 45 & 60.8 & 0.04 & NO \\
\hline Handrail & 11 & 28.2 & 28 & 71.8 & 0.001 & YES \\
\hline Many objects & 79 & 51.3 & 75 & 48.7 & 0.848 & NO \\
\hline Low toilet & - & - & - & - & - & -- \\
\hline
\end{tabular}

Source: Data from the matrix research, 2017

Caption: $X^{2}-$ Chi-square test.

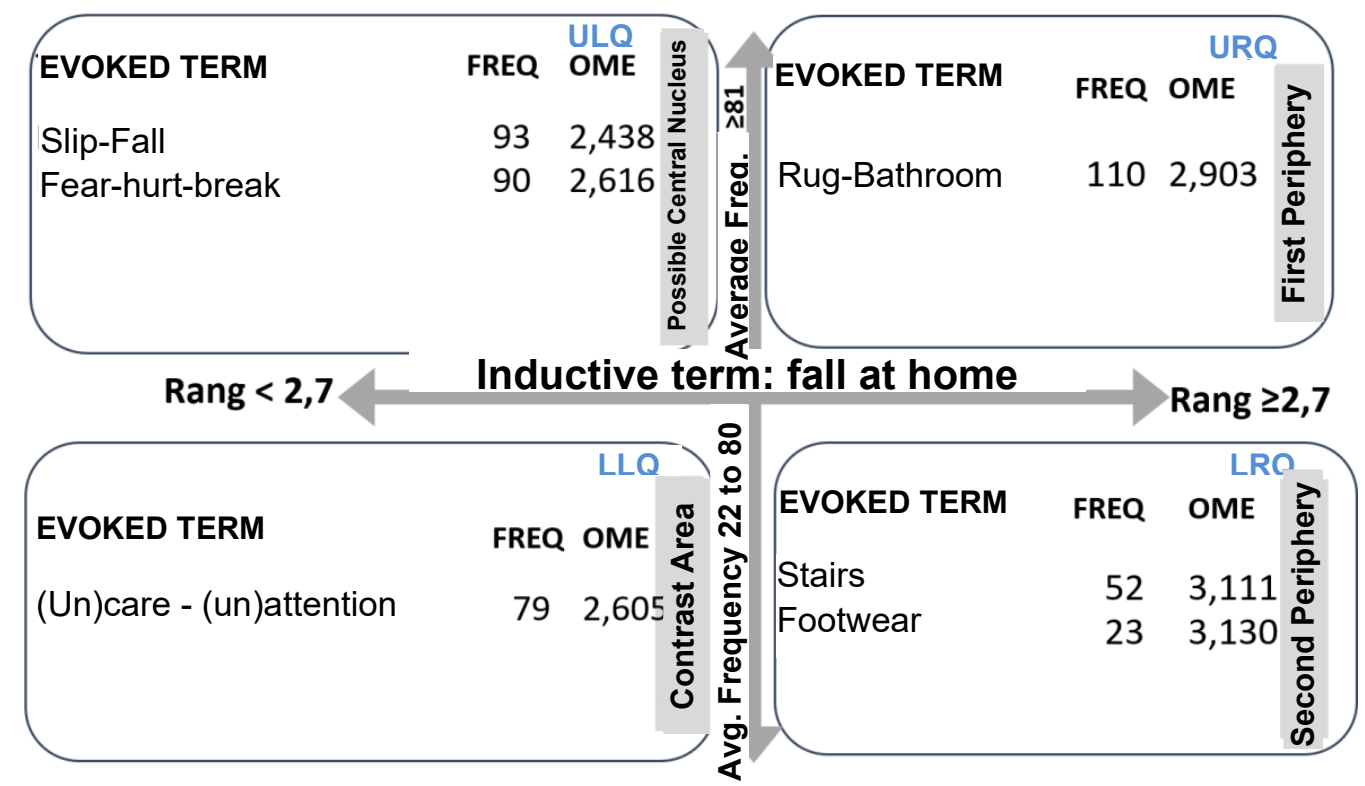

Figure 1 - Four quadrant chart obtained from the inductive term "fall at home". MG, Brazil, 2020 Source: Data from the matrix research, 2017. 


\begin{tabular}{|c|c|c|c|}
\hline \multirow{2}{*}{\multicolumn{2}{|c|}{$* / * *$}} & \multicolumn{2}{|c|}{ Fragment of exemplary speeches according to representational dimensions } \\
\hline & & $\begin{array}{l}\text { Representation of the (in)adaptability } \\
\text { of the home environment }\end{array}$ & $\begin{array}{c}\text { Representation and overcoming limitations } \\
\text { arising from weaknesses }\end{array}$ \\
\hline \multicolumn{2}{|c|}{ 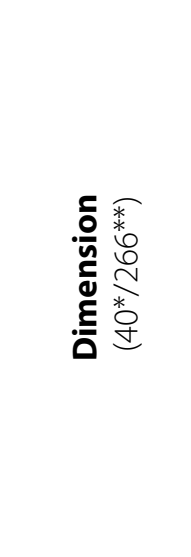 } & $\begin{array}{l}\text { Behavioral and attitudinal: I can fall at home; l even fell down P183. } \\
\text { I'm afraid to raise my Arms P189. I am afraid of having a vertigo P189. I } \\
\text { went to take off a skirt and stepped on it with a slipper on the smooth floor } \\
\text { and slipped P178. } \\
\text { COGNITIVE AND informative: But you have to be very careful at home } \\
\text { too P165. [...]Slippery floor P142. I think the person has to be very attentive } \\
\text { and careful P121. Sometimes you can slip, trip P149. } \\
\text { Evaluative: ... I am very afraid of falling. P121. I think the person has to be } \\
\text { very attentive and careful P121. Wet floor, I never fell P188. } \\
\text { Objective: The boy [son] even fixed my bathroom. P111. I am very afraid } \\
\text { of rug and stairs P111. I think it's dangerous to slip, to slip on the rug, in the } \\
\text { bathroom. [...JThe floor can slip, if there is a loose cloth on the floor, it will } \\
\text { slip for nothing. P180. }\end{array}$ & $\begin{array}{l}\text { Behavioral and attitudinal: ... I've been grabbing to keep from turning } \\
\text { [falling]. P180. I clean the house and put everything in place very carefully } \\
\text { P150. But I haven't fallen for a long time, I have more attention P148. } \\
\text { Cognitive and informative: There is a certain amount of dust here, we } \\
\text { can use a cloth, we can forget and use a little soap, washing powder or } \\
\text { detergent and slip and fall P188. Here at home I think I can fall P120. It is } \\
\text { not difficult. I can fall inside home P114. [...]Because of the rug and worn } \\
\text { slipper P140. I have never fell inside home P166. EVALUATIVE: I walk very } \\
\text { carefully P174. It's not even good to wear slippers, but in that heat, how do } \\
\text { you do it? P140. } \\
\text { Objectival: I already slipped in bathroom P131. To take a shower, you } \\
\text { have to stop holding the bathroom (safety bar) P120. [...JThe slipper } \\
\text { doubled and I fell P140. }\end{array}$ \\
\hline \multirow{2}{*}{ 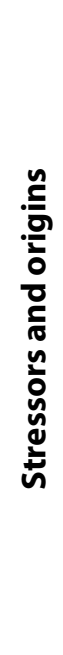 } & 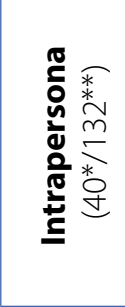 & $\begin{array}{l}\text { Own origin: I'm already ninety, it's not a day, right? P111. } \\
\text { I am terrified of falling. P120 } \\
\text { I bathe alone and never fall P114. } \\
\text { Break something, hit your head on the floor and don't walk anynore P167. } \\
\text { I think it can bring health problems, give a hip fracture, break a leg, displace } \\
\text { something. I think if it falls it breaks, because the bones are no longer } \\
\text { strong P177. }\end{array}$ & $\begin{array}{l}\text { Own origin: I walk very carefully [...] P174. } \\
\text { Because I don't trust that leg (left). P160 } \\
\text { I joke about my fall that was my height. I didn't trip and I didn't slip. When } \\
\text { you trip, you fall forward, when you slide, you fall back. Mine was like this: } \\
\text { simply at my height, I didn't have dizziness or imbalance P181. We can } \\
\text { grate the face. If you don't protect it when you fall, your nose is thin. I fell } \\
\text { with my legs up, then they had to get me up P166. }\end{array}$ \\
\hline & 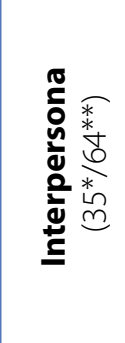 & $\begin{array}{l}\text { Family origin: The boy (son) even fixed my bathroom P111. } \\
\text { This one (husband) has already fallen many times P142. } \\
\text { Colleagues origin: She fell into the box. She got up in the morning and } \\
\text { went to the bathroom. Her husband was waiting for her to come back } \\
\text { and she didn't. When he got there, she was debating P117. I haven't seen } \\
\text { anyone fall for a long time P119. }\end{array}$ & $\begin{array}{l}\text { Family origin: [...]I had to tell my granddaughter, because I am afraid not } \\
\text { to speak and for me to be worse. P138 As soon as I lost my husband, I fell in } \\
\text { the kitchen, but I didn't feel anything, just fell and lay on the cold floor P177 } \\
\text { My husband was always falling P149. } \\
\text { Colleagues/friends origin: This colleague of mine who was changing } \\
\text { the lamp, made him dizzy P183. My girl's godfather, unbalanced and } \\
\text { broke the femur, had the surgery, but gave pulmonary embolism and } \\
\text { died P189. }\end{array}$ \\
\hline
\end{tabular}

Chart 2 - Fragments of exemplary discourses of representational dimensions and origins of stressors 


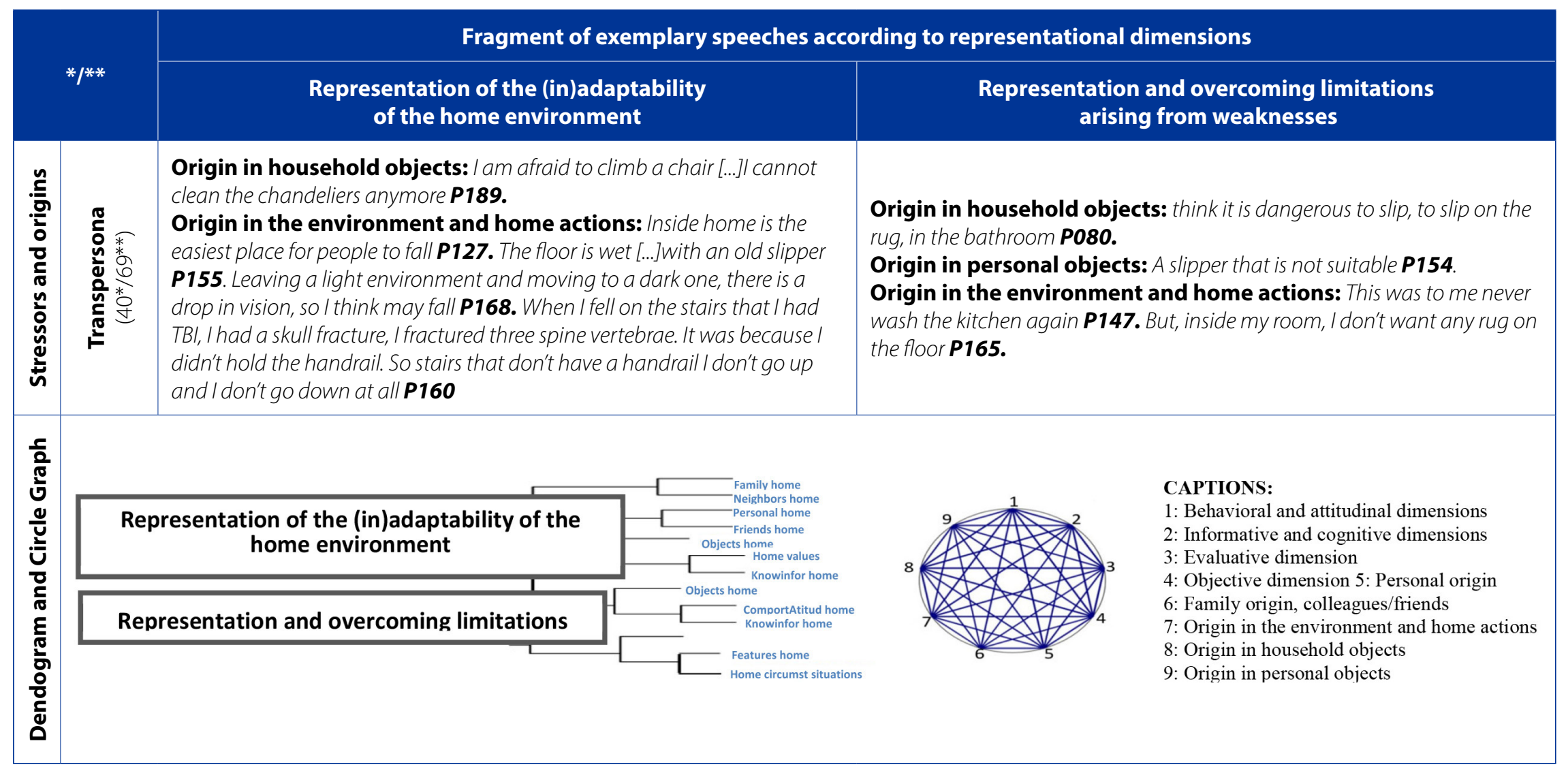

Chart 2 - Cont.

Source: Data from the matrix research, 2017

Author' 'note: * number of participants, *** number of speech fragments. 
the other hand, it can be assumed that for some of these women, the stay of the partner in the home increases the demands of domestic activities that can be a potential for risk factors for falling, both due to the greater number of tasks and physical and emotional demanded by the change of routine.

A randomized experimental study proves that the decrease in visual acuity is considered one of the main risk factors for falls $s^{(5)}$. Thus, visual limitations are considered intrapersonal stressors ${ }^{(9)}$. Under normal conditions, clinical practice points out to the referral of people with this disability for treatment and visual correction to minimize their risk of falls. However, a possible perception of the elderly about the restriction on the home as prevention in the pandemic, can be wrongly understood as a recommendation to stay away from the health units or even experiences of fear of contamination can lead to interruption or postponement of health assessments and essential periodic therapeutic regimens, which would increase the stressor spectrum of visual limitations.

The empirical study demonstrated that the elderly people who presented the fear of falls evaluated by the Falls Efficacy Scale, $53.5 \%$ had a score greater $\geq 23$ points, which is to say that the majority of the participants lived with the feeling of fear in the development of their daily life activities. This scale was used in a study carried out in Saudi Arabia ${ }^{(5)}$, in which $57 \%$ of participants aged $\geq 60$ years had a previous history of falls, being identified a statistical association with changes in gait, use of assistive technology and intravenous hydration, an environment with lots of furniture, fragile people, with memory lapses, who neglected their limitations, older elderly and women ${ }^{(19)}$

The elements contained in the possible central nucleus of the four quadrant chart constructed from the evoked term "fall at home" were: "slip-fall", "fear-hurt-break". The primary positions and with high frequency in the quotation of the participants allows to portray that the components are consensualized in the investigated social group ${ }^{(7)}$.

The "slip-fall" cognema, as it reconciles higher frequency and lower $\mathrm{OME}$, can be considered a prominent element within the central nucleus and its content is linked to the behavior of elderly people who have had the experience of falling directly or indirectly.

The "fear" variable emerged in the process of representing the elderly in the study in question. The cognemas "fear-hurt-break" and "slip-fall" integrate the possible central nucleus in the structural approach, the fact that they were mentioned with high frequency and more readily refers to the idea of behaviors and feelings present in the memory of individuals facing the possibility of falling and portraying the possibility of insecure behavior in the process of home displacement.

The components of the central nucleus portray a causal relationship, in which "fear-hurt-fall" originates from the negative "slip-fall" behavior, establishing a consequence. The elements of the central nucleus and presented in the speeches establish the justification function ${ }^{(8)}$ of social representation, as it allows the elderly to explain and justify their fearful behaviors and behaviors in the face of the possibility of falling. The contents presented portray the representational elements and their hierarchical process, accompanied by the participants'speeches, obtained through recorded interviews.

From the inductive term "fall at home", it was possible to access these elements and their hierarchical allocation regarding falls from the collective perspective of the participants, identifying the cognemas regarding the behavioral dimension "Slip-fall", aimed at by justified by the behavior/ feeling of "fear-hurt-fall", a possible triggering factor for the fall. The structural and procedural approach of SRT allowed the responses to converge, the results being corroborated by the adopted investigative methodologies.

There is evidence in the literature that the occurrence of falls is a common element among people in the aging process ${ }^{(19)}$. Current circumstances of confinement and fear of contamination may have heightened the fear of falling at home. It must be considered that both the elderly and other people who live with them implement routines, which, if not conducted with caution, may offer more risk. For example, the recommendation of more intensive floor cleaning tends to make the surface slippery more frequently. Likewise, disinfecting products purchased on the market can be a complex task and can cause more surfaces to get wet, increasing the risk of falling, especially among elderly people who must engage directly in the task.

The content of the evoked words/expressions that were allocated in the upper right quadrant (URQ), that is, in the first periphery, behaving among the hierarchical elements as an overactivated and objective periphery, in which the frequency of the cognemas is high, higher than the frequencies present in the possible central nucleus, however it was not a cognema evoked promptly by the participants. However, it portrays objects found at home and that place participants in the condition of vulnerability to falls, mainly due to the fact that these conditions portray something present in their daily lives.

The objectification in the first periphery portrayed by the cognema "rug-bathroom" is related to the fact of the home environment, specifically the bathroom area can be recognized as the place that favors the occurrence of falls among 
the elderly, being the rug object a potentializer of this event. In the face of episodes of contamination in the pandemic, an increase in the frequency of hand washing and bathing has been indicated, which may be a factor to increase the fear with the occurrence of falls in the bathroom, leading the elderly to make a decision that they can to conform between preventing contamination versus preventing falls.

The cognema expressed by the participants makes it possible to extract the function of knowledge ${ }^{8}$ from social representation, in which health professionals have the possibility of promoting their educational actions based on information and knowledge that are understood and assimilated in the participants' common sense, capable of portraying the reality of what is socially shared. However, the overload condition of the health system in the care of severe cases of patients ill by COVID-19 is probably directing the focus of action towards emergency situations linked to the preservation of vital functions, particularly the conditions of ventilation and gas exchange.

Evidence reinforces that the environmental risk involving the home is a predictor of falls. Home risk factors, in most cases, are modifiable, reinforcing the need to implement preventive guidelines and measures related to the risk of falls. However, the unique situation of the pandemic makes it difficult to modify risk factors in the home environment, including in view of the difficulty or contraindication to hiring personnel and purchasing materials for reforms that could increase environmental security, offsetting the new conformation of risk factors ${ }^{(20)}$.

The cognema "(un)care-(un)attention" located in the lower left quadrant (LLQ), representing the contrast area of the four-quadrant chart, was identified at the time of collection in a context of free movement of participants. Today, faced with a necessary confinement in their homes, the elderly can experience a sense of inattention to their health needs and, on the other hand, experience an increase in the need for self-care. Elderly people, as well as the general population, have been invited to reflect on their physical and mental health standards, giving relevance to the reorganization of routines, dream, diet, exercise and self-care skills ${ }^{(20)}$.

In the lower right quadrant (LRQ), located the second periphery contains elements, a hierarchical region in which the elements with low frequency of evocation and mentioned in the last positions are allocated. The elements "stairs" and "footwear" are classified as an object of representation, and establishes an orientation function, as they can direct the way the components of the social group should behave in the face of peculiar objects, but liable to become risk factors for falls.
Before the pandemic, "stairs" was referred to as a favorable place for falls to occur, even in the triangulation of quantitative data, with significant significance in the comparison with falling people and self-perception of the risk of falling from stairs. The object "footwear" represents an element that associated with the weaknesses resulting from the aging process is an element that triggers falls. Currently, there may be new representations and configurations for stressors such as stairs, handrails, and steps.

It can be conjectured that given the permanence information of the Sars-CoV-2 virus on metallic surfaces and in shoes, they can lead the elderly to actions that can increase their risk of falling, among them: preferring stairs to confining elevators if they are few floors, avoid using the handrail when descending or climbing steps and using inappropriate shoes when they have to leave the house in the face of difficulties of contamination or fear of with this process damaging more appropriate shoes to prevent falls.

The study, using quantitative and qualitative evidence of falls of the elderly at home and producing conjectures, advances the knowledge, indicating considerations that need to be submitted to investigation in new field research to test the established theoretical hypotheses. The recent emergence of the pandemic and the concentration of studies on topics linked to elements of illness are factors that indicate the potential of this manuscript to produce original "insights" that can be more carefully verified.

\section{a CONCLUSION}

The personal and home structure conditions were described as stressors, among them: rug, security bar, lighting, slippery floors, steps, stairs, handrails, and many objects in the environment. Its implications on the representations of the elderly already demonstrated a strong relationship with the fall, expectation, or fears of falling before the occurrence of pandemic by COVID-19.

Since the home is an environment with a relevant impact on the life of the elderly person, regardless of their level of limitations and abilities, it was possible to produce conjectures based on the evidence of fieldwork in the current situation that arises in the dynamics of the pandemic.

The home environment motivates fear and generates vulnerability to fall, identified through the self-perception of participants in the socially constituted group, and it is possible to trigger stressors of intrapersonal, interpersonal, and transpersonal origin. Greater confinement to the home may be a factor to increase the fear for the occurrence of falls.

The present study points out as a main limitation the possibility of having left out qualitative impressions in the 
application of theoretical conjectures. In fact, the theoretical conjecture is an exercise of fundamentally deductive reasoning whereas the production of qualitative evidence follows the path of induction. Despite this, reflections and findings are brought that are relevant to the current scenario in the face of the health crisis established in the world. In addition, it sheds light on a little-explored face of the change in lifestyle resulting from the pandemic and from which we do not have epidemiological indicators or qualitative inferences. Thus, this research contributes as a starting point with implications for future studies in the mentioned investigation designs.

\section{REFERENCES}

1. Santos JC, Arreguy-Sena C, Pinto PF, Pereira EP, Alves MS, Loures FB. Social representation of elderly people on falls: structural analysis and in the light of Neuman. Rev Bras Enferm. 2018;71(suppl 2):851-9. doi: https://doi. org/10.1590/0034-7167-2017-0258

2. World Health Organization (CH). Geneva: WHO; c2018-2020 [cited 2020 May 20]. Falls; [about 1 screen]. Available from: https://www.who.int/news-room/ fact-sheets/detail/falls

3. Barros IFO, Pereira MB, Weiller TH, Anversa ETR. [Hospitalizations due to falls among elderly Brazilians and related costs under the Public Health System]. Rev Kairos. 2015 [cited 2020 May 20];18(4):63-80. Portuguese. Available from: https://revistas.pucsp.br/kairos/article/view/26930/19124

4. Hammerschmidt KSA, Santana RF. Health of the older adults in times of the covid-19 pandemic. Cogitare Enferm. 2020. 25:e7284. doi: https://doi. org/10.5380/ce.v25i0.72849

5. Alshammari SA, Alhassan AM, Aldawsari MA, Bazuhair F0, Alotaibi FK, Aldakhil $A A$, et al. Falls among elderly and its relation with their health problems and surrounding environmental factors in Riyadh. J Family Community Med. 2018;25(1):29-34. doi: https://doi.org/10.4103/jfcm. JFCM_48_17

6. Moscovici S. Representações sociais: investigações em psicologia Social. 11 ed. Petrópolis: Vozes; 2015.

7. Abric JC. Prácticas sociales y representaciones. 13 ed. México, DF: Ediciones Coyoacán; 2013.
8. Sá CP. Estudos de Psicologia Social: História, Comportamento, Representações e Memória. Rio de Janeiro, RJ: Ed Uerj; 2015.

9. Neuman BM, Fawcett J. The Neuman systems model. Boston: Pearson; 2011.

10. Creswekk JW, Clarck VLP. Designing and conducting mixed methods research, 3rd Edition. Thousand Oaks: SAGE; 2017.

11. Rothman KJ, Greenland S, Lash TL. Epidemiologia moderna 3 a ed. Porto Alegre: Artmed; 2011.

12. Hong QN, Fàbregues S, Bartlett G, Boardman F, Cargo M, Dagenais $P$, et al. The Mixed Methods Appraisal Tool (MMAT) version 2018 for information professionals and researchers. Educ Inform. 2018;34(4):285-91. doi: https:// doi.org/10.3233/EFI-180221

13. Cohen J. A power primer. Psychol Bull. 1992;112(1):155-9. doi: https://doi. org/10.1037//0033-2909.112.1.15

14. Ministério da Saúde (BR), Ministério da Educação (BR). Projeto Olhar Brasil: triagem de acuidade visual, manual de orientação. Brasília, DF: Ministério da Saúde; 2008 [cited 2020 May 20]. Available from: http://portal.mec.gov. br/index.php?option=com_docman\&view=download\&alias=1863-psemanual-olharbrasil\&ltemid $=30192$

15. Camargos FF, Dias RC, Dias JMD, Freire MTF. Cross-cultural adaptation and evaluation ofthepsychometric properties of theFallsEfficacy Scale-International Among Elderly Brazilians (FES-I-BRAZIL). Ver Bras Fisioter, 2010;14(3):237-43. doi: https://doi.org/10.1590/S1413-35552010000300010

16. Bardin L. Análise de conteúdo. Lisboa: Edições 70; 2016.

17. Nascimento LCN, Souza TV, Moraes JRMM, Aguiar RCB, Silva LF. Theoretical saturation in qualitative research: an experience report in interview with school children. Rev Bras Enferm. 2018;71(1):228-33. doi: https://doi. org/10.1590/0034-7167-2016-0616

18. Lopez-Benavente Y, Arnau-Sánchez J, Ros-Sanchez T, Lidón-Cerezuela MB, Serrano-Noguera A, Medina-Abellán MD. Difficulties and motivations for physical exercise in women older than 65 years: a qualitative study. Rev Latino-Am. Enfermagem. 2018;26:e2989. doi: https://doi. org/10.1590/1518-8345.2392.2989

19. Saftari LN, Kwon 0-S. Ageing vision and falls: a review. J Physiol Anthropol. 2018; 37(11):1-11. doi: https://doi.org/10.1186/s40101-018-0170-1

20. Morrow-Howell N, Galucia N, Swinford E. Recovering from the COVID-19 pandemic: a focus on older adults. J Aging Soc Policy. 2020;32(4-5):526-35. doi: https://doi.org/10.1080/08959420.2020.1759758 


\section{- Acknowledgments:}

To the Coordination for the Improvement of Higher Education Personnel (Coordenação de Aperfeiçoamento de Pessoal de Nivel Superior - CAPES) for the scholarship granted.

\section{- Authorship contribution:}

Conceptualization: Jéssica de Castro Santos; Cristina Arreguy-Senna; Marcos Antônio Gomes Brandão.

Data curation: Jéssica de Castro Santos; Cristina Arreguy-Senna; Marcos Antônio Gomes Brandão.

Formal analysis: Jéssica de Castro Santos; Cristina Arreguy-Senna; Paulo Ferreira Pinto; Marcos Antônio Gomes Brandão.

Investigation: Jéssica de Castro Santos; Cristina Arreguy-Senna.

Methodology: Jéssica de Castro Santos; Cristina Arreguy-Senna.

Visualization: Jéssica de Castro Santos; Cristina Arreguy-Senna; Paulo Ferreira Pinto; Elenir Pereira de Paiva; Pedro Miguel dos Santos Dinis Parreira; Marcos Antônio Gomes Brandão.

Writing-original draft: Jéssica de Castro Santos; Cristina Arreguy-Senna; Paulo Ferreira Pinto; Pedro Miguel dos Santos Dinis Parreira; Marcos Antônio Gomes Brandão. Writing-review \& editing: Jéssica de Castro Santos; Cristina Arreguy-Senna; Paulo Ferreira Pinto; Elenir Pereira de Paiva; Pedro Miguel dos Santos Dinis Parreira; Marcos Antônio Gomes Brandão.

\section{- Corresponding author:}

Jéssica de Castro Santos

Email: jessicacastroenf@gmail.com

\section{Associate editor:}

Dagmar Elaine Kaiser 